\title{
Transnational Governmentality and the Politics of Life and Death SIMA SHAKHSARI
}

\author{
Department of Women's and Gender Studies, Wellesley College, Wellesley, \\ Mass.; e-mail: sshakhsa@wellesley.edu \\ doi:10.1017/S0020743813000081
}

One can ignore neither the role of diasporas nor colonial and imperial discourses of modernity in the construction of normative sexual identities and practices in the Middle East, whether in the past or the present. This is not to dismiss "local" forms of regulation, disciplining, and normalization of queers, but to point to the way that "local" state and nonstate norms of sexuality are not detached from "global" trends and transnational relationships of power. My own work on gender and sexuality within Iranian diasporic contexts engages with scholarship that postulates sexuality as a form of transnational governmentality ${ }^{1}$ and with analyses of homonationalism ${ }^{2}$ and necropolitics. ${ }^{3}$ I examine the representational economy of queer deaths during the "war on terror" and suggest that the Iranian transgender refugee, who has become a highly representable subject as a victim of Iranian transphobia in the civilizational discourses of the "war on terror," dies an unspeakable death if her death disrupts the promise of freedom after flight.

Although it is the individual who is subjected to the management of life through biopower, as Foucault has argued, it is the population that is the target of the art of governmentality. Yet, the concept of biopolitics may not be sufficient to analyze the global division of populations into those whose lives are produced and managed and those whose lives are deemed disposable, not solely by the juridical sovereign power of the state but also by international entities and transnational market-driven actors. Achille Mbembe's notion of necropolitics, which focuses more on the place given to death in relation to human bodies and their inscription in the order of power, is helpful in thinking about the disposability of Iranian transgender lives. Mbembe argues that modern colonial occupation combines the disciplinary, the biopolitical, and the necropolitical, as the state of exception and the state of siege become the normative basis of the right to kill.

I draw on the concepts of biopolitics and necropolitics to suggest the politics of rightful killing as a form of power in the contemporary political situation, wherein those whose rights and protection are presented as the raison d'être of war are sanctioned to death and therefore live a pending death precisely because of those rights. Within the rhetoric of the "war on terror," the "people of Iran" are constituted as a population for which death through sanctions and/or bombs is legitimized. Unlike Giorgio Agamben's concept of homo sacer - he who may be killed but not sacrificed, who is reduced to bare life in the "state of exception" and stripped of rights-those subjected to the politics of rightful killing in the war on terror cannot be killed by just anyone (certainly not by the illiberal states), but can be righteously killed by the liberating states, in the name of rights, democracy, free market, and global security. ${ }^{4}$

If the Iranian population at large is subjected to the politics of rightful killing, how does the Iranian transgender refugee figure in the state of normalcy that characterizes the "war on terror"? As Agamben argues, the concentration camp is the nomos of modernity where the state of exception becomes the rule of law. I suggest that the camp as state of 
exception signifies both the body-in-excess and the location one occupies as a refugee, and as such can highlight the limitation of rights associated with the converged notions of the natural and the political. Shuttling between life and death, the transgender refugee is caught between biopolitics and necropolitics, where her body is produced and managed through religious, medical, psychological, and geopolitical discourses, and her death is sanctioned in the state of exception as a refugee (outside of the nation-state) and as transgender (outside of the naturalized binaries of sex).

Representations of Iranian transsexual individuals by the "gay international"5 have made them the center of a particular discourse on homosexuality, in which transsexual Iranians are represented as homosexual victims who are forced by the Iranian state to go through sex reassignment surgeries (SRS). ${ }^{6}$ Surgeries, in this narrative, are seen as state measures to prevent homosexuality, while transsexual Iranians' desires are deemed inauthentic and secondary to an inherent homosexual desire that is persecuted by the state. ${ }^{7}$ Despite government subsidies for SRS, the economic and social hardship and discrimination that many transgender and transsexual Iranians endure, along with the valorized vision of freedom and democracy in the West, compels some to seek refugee status in Canada, Australia, and the U.S. through the United Nations High Commissioner for Refugees (UNHCR) offices in neighboring Turkey.

While the Iranian state seeks to "correct" gender ambivalent bodies by disciplining them into heterosexual norms, international human rights regimes produce transgender Iranians as subjects of universal rights, in need of protection. Ironically, it is under the rhetoric of protection that the refugee has little or no rights in transitioning across borders. Faced with xenophobic and transphobic violence, refugee applicants live under dire conditions in small Turkish border towns, where they are required to stay for several years while they wait for their UNHCR and embassy interviews. In order to present believable claims to interviewers, refugee applicants often have to repeat normative notions of gender and sexuality, and demonize the "home country." The normalization of transgender refugees involves a network of governmental and nongovernmental organizations, civilizational discourses, techniques of self, and calculation methods (interviews, surveys, expert testimonies) that seek to prevent deception and threats to the national and international security regimes.

The case of Mahtab may shed light on the politics of life and death in relation to geopolitical discourses that implicate transgender Iranian refugees. A transgender Iranian woman, Mahtab was one of around 300 Iranian queer refugees in remote "satellite towns" in Turkey, awaiting their cases to be handled by the UNHCR in Ankara. After several years there, she received refugee status in Canada and, with the help of a nonprofit Canadian organization, moved to Toronto. While living in Iran and Turkey, Mahtab was the subject of several documentary films that juxtaposed a repressed life in Iran to a free queer/trans life in the West. ${ }^{8}$ Unlike her story of suffering in Iran, Mahtab's experience of poverty and alienation in Canada never made it into any films or news reports. In 2008, almost a year after immigrating, she committed suicide in an apartment she was asked to vacate, as the terms of her subsidized housing had come to an end. ${ }^{9}$ Mahtab's unspeakable death, and the disposability of the lives of Iranian transgender refugees in Turkey, highlights the connection between biopolitics, necropolitics, and geopolitics, attesting to the untenability of populations that are simultaneously imbued with and stripped of liberal universal rights. 
The study of queer lives and deaths in the context of the Middle East needs to address the centrality of sexuality within past and present colonial projects (even in locations that were/are ostensibly not colonized) and to explore how movements of bodies and information change articulations of desire within and beyond national and regional borders. Queer lives and deaths in the Middle East are inevitably connected to normalizing and disciplinary measures that go beyond the state repression of homosexuality. Middle East studies needs to engage with the study of sexuality within a transnational assemblage of medical and cyber technologies, national and religious discourses, international refugee and human rights regimes, and neocolonial and neoliberal forms of subject formation.

\section{NOTES}

${ }^{1}$ Akhil Gupta and James Ferguson expand the Foucauldian notion of governmentality to include strategies of regulation and discipline imposed by complex international and transnational networks and diasporic flows of people, information, and capital. Ferguson and Gupta, "Spatializing States: Toward an Ethnography of Neoliberal Governmentality," American Ethnologist 29 (2002): 981-1002. On sexuality in relation to transnational governmentality, see Paul Amar, The Security Archipelago: 'Human Security' States, Sexuality Politics and the End of Neoliberalism (Durham, N.C.: Duke University Press, 2001).

${ }^{2}$ Jasbir Puar, Terrorist Assemblages: Homonationalism in Queer Times (Durham, N.C.: Duke University Press, 2007).

${ }^{3}$ Achille Mbembe, "Necropolitics," trans. Libby Meintjes, Public Culture 15 (2003): 11-40. For this concept in queer theory, see Jin Haritaworn et al., eds., Queer Necropolitics (Routledge, forthcoming).

${ }^{4}$ Giorgio Agamben, Homo Sacer: Sovereign Power and Bare Life (Stanford, Calif.: Stanford University Press, 1998).

${ }^{5}$ Joseph A. Massad, Desiring Arabs (Chicago: University of Chicago Press, 2007).

${ }^{6}$ For example, see http://www.theweek.co.uk/26319/drastic-surgery-iran\%E2\%80\%99s-gay-men (accessed 17 January 2013).

${ }^{7}$ Postrevolutionary Iran has seen a proliferation of sex reassignment surgeries in the wake of Imam Khomeini's fatwa making these surgeries religiously and legally permissible. See http://www.nytimes.com/2004/08/ 02/international $/$ middleeast $/ 02$ iran.html?pagewanted $=1 \&$ ei $=5090 \&$ en $=97 \mathrm{bb} 9 \mathrm{ba} 99064 \mathrm{~d} 599 \& \mathrm{ex}=12490992$ 00\&partner=rssuserl; http://www.guardian.co.uk/world/2005/jul/27/gayrights.iran; and http://www.guardian . co.uk/world/2007/sep/25/iran.roberttait (all accessed 15 September 2011).

${ }^{8}$ For example, Mahtab's statement "I know that I am" was the title of an award-winning Canadian documentary film representing transsexual Iranians as victims of a fundamentalist state, in need of rescue by the "free world." I Know that I Am, dir. Peyman Khosravi and Babak Yousefi (Iran/Canada, 2006). For a promotional video of this film see http://www.youtube.com/watch?v=wF_WOnSndgQ\&feature=related.

${ }^{9}$ It was only in 2010 that the International Lesbian and Gay Association (ILGA) published a sensationalized story about Iranian transgender people that mentions Mahtab's death in Canada, but focuses on the story of abuses she experienced in Iran. There is little or no advocacy on behalf of queer refugees after their arrival in a third country of asylum such as the United States or Canada, where very few job opportunities and services are available to refugees in a market economy where the individual is increasingly responsible for her or his own economic well-being. For ILGA's report see http://ilga.org/ilga/en/article/miNFHPm1NI (accessed 15 September 2011). 